\title{
CNN founder launches arms control initiative
}

Irwin Goodwin, Washington

Lately, international arms control has looked like a cause fast falling out of fashion. Memories of the cold war are fading, the population thinks about nuclear danger less, and, in the United States, the new administration of George W. Bush expresses more interest in missile defence systems than in arms control agreements.

So those who see arms control as a matter of critical importance have reacted with enthusiasm to last week's announcement by Ted Turner, the wealthy founder of the CNN television network, that he will sponsor a major new arms control institute to the tune of $\$ 250$ million over five years.

The non-profit Nuclear Threat Initiative will be devoted to reducing the threat of nuclear arms and other weapons of mass destruction, Turner says.

He convinced former Senator Sam Nunn to become vice-chairman of the organization. Nunn, a Democrat who represented Georgia, in turn enlisted two prominent Republican senators, Richard Lugar of Indiana and Pete Domenici of New Mexico, to serve on the initiative's board.

Turner says that the new organization's mission is "even more urgent now as the nuclear threat seems to have fallen off most people's radar screens since the cold war ended".
Nunn and Charles Curtis, a highly regarded former deputy secretary of energy who will be the organization's chief operating officer, have already met with defence ministers in Britain and France to win support for their work.

The new organization does not plan to duplicate existing government programmes, or provide grants directly to research in arms control. Instead, it will seek to raise public consciousness and understanding of the problems and to gain government support for arms control initiatives. "We intend to be a catalyst in education and to encourage change in reducing pressure on the nuclear trigger," Curtis says.

One of the organization's priorities will be to support educational activities through universities, non-governmental groups and government agencies.

In an interview, Curtis emphasized the need to invigorate scholarship in arms control. "There has been a steady decline in arms control as a career path," he says. Stanford University in California and Harvard still teach arms control, but the Massachusetts Institute of Technology has abandoned its programme.

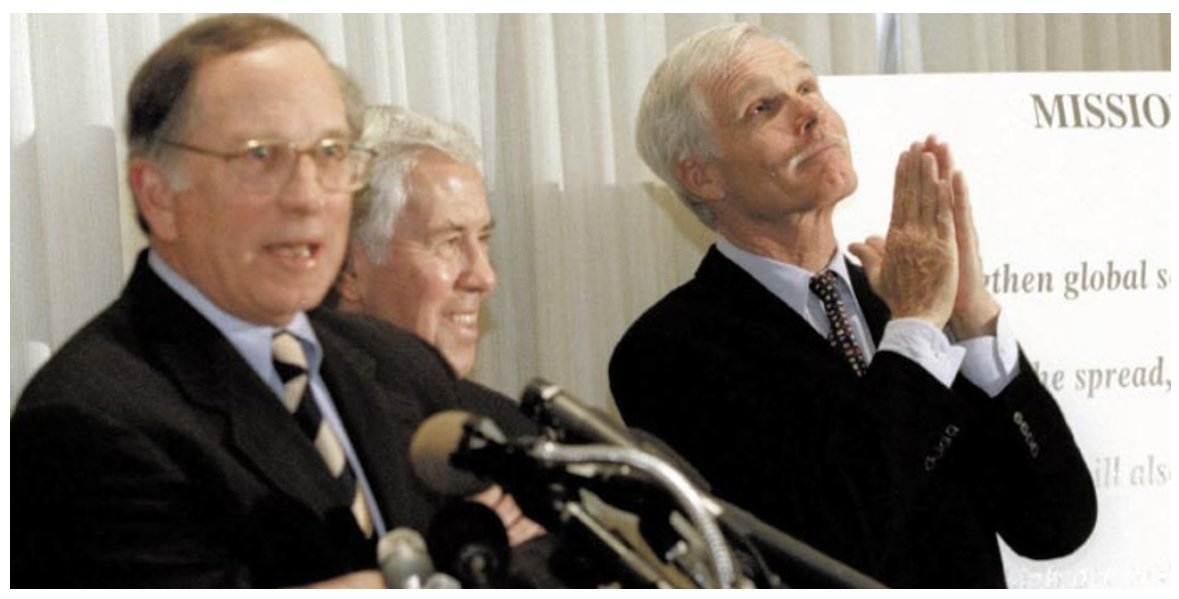

Prayers for peace: from left, Sam Nunn, Richard Luger and Ted Turner at the organization's launch.

\section{BSE fallout sends shock waves through Germany}

Alison Abbott, Munich

Consumer panic has disrupted German meat markets after the discovery of a small number of bovine spongiform encephalopathy (BSE) cases in German-

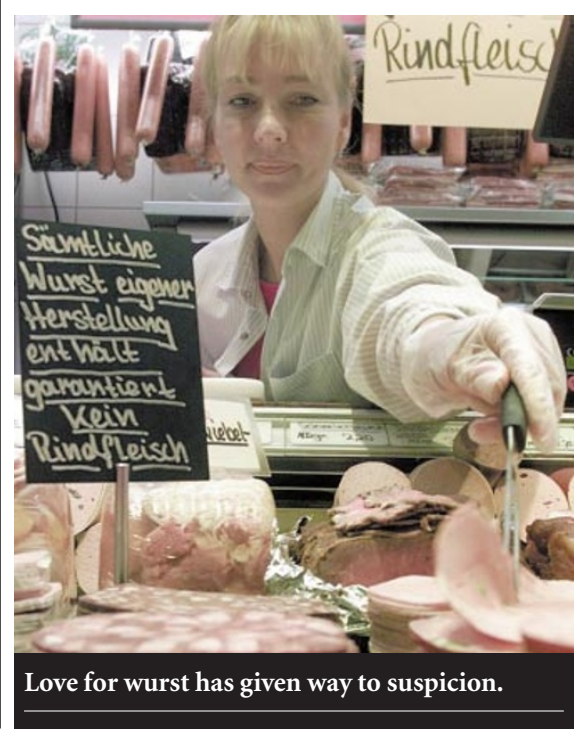

born cattle. As the government attempts to get a grip on the crisis, the agriculture and health ministers have lost their jobs, and food-supply regulation and research are set for a major shake-up.

Andrea Fischer, the health minister and a member of the Green Party, resigned last week, following accusations that she mismanaged the recent crisis. She lost credibility after making confused statements over which types of sausages contain beef.

And Social Democrat Karl-Heinz Funke, the agriculture minister, resigned after criticism that his department had been slow to enforce a ban on the use of mechanically recovered meat in sausages.

The replacements for the two departed ministers will maintain the existing balance in Germany's governing coalition of Greens and Social Democrats. The new health minister is Ulla Schmidt, a Social Democrat, but part of her ministry's competence consumer protection - will move to the agriculture ministry.

In an attempt to restore consumer confidence, the agriculture ministry is being renamed the Ministry for Consumer Protection, Food Safety and Agriculture. Its new boss is Green Renate Künast, who has already responded to the BSE outbreak by announcing plans to encourage movement away from intensive agriculture and towards organic farming. The percentage of agricultural land given over to organic agriculture should increase from 3\% to $10 \%$ in the next five years, Künast says.

Inclusion of consumer protection in the agriculture ministry is an attempt to temper influence of the agricultural lobby over the ministry. It is likely that the Federal Institute for Health-Related Consumer Protection and Veterinary Medicine, one of the health ministry's three scientific offices, will also move to the new agriculture ministry, where it will probably be reorganized.

Like some of its companion offices, the institute has been criticized as inefficient. A report by the Wissenschaftsrat, Germany's science council, suggesting better coordination between ministerial offices, is expected to be approved this week. 